\title{
Méndez Rubio, Antonio (2016): Comunicación musical y cultura popular. Una introducción crítica. Valencia: Tirant Lo Blanch. 407 pp. ISBN: 978-8416556519
}

El término "música" contiene una gran diversidad de rasgos con los que se podría construir una descripción del mismo, y aún así, cualquier definición quedaría incompleta por la amplitud de matices que guarda dentro de sí. A pesar de esta dificultad, no cabe duda de que la música es una manifestación artística desarrollada a lo largo de los tiempos y, como tal, es una actividad multipropósito que no se limita al establecimiento de una mera función estética, sino que incluye un importante objetivo comunicativo entre otras muchas utilidades.

Precisamente el profesor Antonio Méndez Rubio nos plantea en su libro una correlación entre la perspectiva cultural de la música y las diversas y abundantes transacciones comunicativas que guarda este arte. Para alcanzar dicha determinación, el autor ha estructurado la obra en tres bloques: uno de ellos está centrado en el tratamiento de una serie de nociones elementales en el recorrido histórico de la comunicación musical para explicar la unión de la actividad musical con la sociedad a través de la cultura, y para ello se dispone a entablar un análisis comparativo en el relato siempre controvertido entre lo culto y lo popular y cómo han ido evolucionando ambos conceptos y sus significaciones a través del tiempo. La música ha dotado de sentido la comunicación entre las personas ya que éstas son esencialmente simbólicas y han necesitado de este tipo de intercambio para establecer contactos desde los más superficiales a los más profundos. Esta premisa nos llevaría hacia una cuestión de base que se plantea y que consiste en cimentar cuáles son las coincidencias y las diferencias entre el lenguaje que podría denominarse como convencional frente a un lenguaje musical, y quiénes, cómo y en qué contextos sociales se utilizan. En fin, se pretende poner de manifiesto cuáles son los elementos que ponen en contacto la comunicación musical con la cultura popular.

Abordadas estas consideraciones, se realiza una aproximación a la aparición y desarrollo de la industria musical como elemento que sostiene la comunicación musical en el mundo moderno. Con la evolución de las sociedades y la paulatina incorporación de la tecnología, la música va a adquirir un cariz más complejo en tanto que la difusión de ésta tendrá un mayor alcance y los agentes que entran en juego son cada vez más amplios y tienen una mayor interdependencia, actuando sobre las múltiples facetas que tiene adheridas este sistema: desde lo jurídicolegal, por cuestiones como los derechos de propiedad; hasta lo ideológico-cultural, como el dar un determinado valor a un tipo de música y sujeto creador por medio de otros canales como el cine o la televisión; pasando por lo comercial, como la venta de soportes de reproducción mecánica de las melodías, entre otros. La industria musical va a discurrir, desde su aparición, por tres fases históricas que la caracterizan desde finales del siglo XIX hasta nuestros días.

Haciendo una mirada retrospectiva se destaca cómo el pensamiento tradicional sometía al ostracismo a las músicas populares rechazándolas de plano en contraposición con el ideal de música (culta), que en el clasicismo se dotaba de unos valores supremos frente a la anterior. Pero en su desarrollo, y con la presencia ya de la industria, la música sufrirá un proceso de homogeneización para cumplir con las pautas de estandarización de la producción en las sociedades de consumo en donde los gustos y modas musicales los alimenta la propia industria del sector y en donde entran en juego variados intereses como el económico, el ideológico o el mediático.

Por otro lado se aborda explícitamente la música rock como cultura y con ello se ponen de manifiesto las relaciones tormentosas-amistosas entre la cultura popular y la cultura masiva; se hace un recorrido histórico por los cimientos de este estilo desde su surgimiento a lo largo de la década de los años 50 del siglo XX hasta sus nuevas adaptaciones en el mundo actual. En la descripción de todo el camino recorrido podemos discernir los diferentes avatares por los que ha pasado. El rock' n' roll es un claro ejemplo de cómo este tipo de música popular no puede ser desligada de las condiciones y pautas culturales que la rodean para poder comprenderla. Nace de la confluencia de varios géneros musicales como el rhythm and blues, el country o el jazz entre otros, que están cada uno de ellos adheridos a diferentes subculturas y estilos de vida.

El contexto social y político en el que se desarrolla está caracterizado fundamentalmente por el ambiente de conflictividad social imperante derivado de las tensiones raciales de la época en los EE.UU. Por esto y por otros añadidos el rock ha sido vinculado, desde su fundación, a la rebelión de los jóvenes contra lo convencional de las normas sociales y políticas establecidas. A finales de la década de los 50 , con la aparición de Elvis Presley, este estilo musical va a consolidar sus principales rasgos de identidad: un movimiento contracultural que da de alguna manera voz a los jóvenes inconformistas y les hace ser miembros de un grupo de pertenencia con unos valores y creencias propias, y con múltiples significados vertebrados en singulares indumentarias, peinados y accesorios, formas de hablar, de pensar y de sentir que configuran toda una forma de ver la vida. 
Con Elvis se puede entender la situación del tira y afloja entre las subculturas y los medios de masas, y sus apariciones en televisión o en el cine van a extender el rock and roll hasta situarlo en una posición privilegiada en lo que se ha denominado la "edad de oro" de este estilo musical. Posteriormente se explicará el itinerario que ha ido transformando el rock en otros subgéneros, con la aparición de sus respectivas subculturas, y las tensiones entre ellas por configurarse como estilos dominantes, y cómo la industria se ha ido apoderando de todas ellas para usarlas en beneficio propio.

En la parte final se tratan las nuevas músicas globales entronizadas por el pop en detrimento del rock y seguidas de otros estilos como el hip hop, la música electrónica y diversos subgéneros más que acaparan la música popular. Con el desarrollo de las tecnologías, el crecimiento de los mercados y la aparición de la gran competencia de la industria musical cambiante, junto con su crisis, se facilitará la fragmentación de estilos. La industria ha ido implementando múltiples innovaciones tecnológicas en estos géneros globalizados con el fin de popularizarlos aún más y de mantener la hegemonía como parte dominante en el sistema y agente que vehicula la comunicación musical con la cultura.

Rubén J. Pérez Redondo Universidad Rey Juan Carlos, España rubenjose.perez@urjc.es

Recibida: 05-4-2016 Aceptada: 10-4-2016 